\title{
Morphology of the female reproductive system of the red-clawed mangrove tree crab (Goniopsis cruentata Latreille, 1803)
}

\author{
LEONARDO PERES DE SOUZA ${ }^{1}$ and JOSÉ ROBERTO FEITOSA SILVA ${ }^{2}$ \\ ${ }^{1}$ Instituto de Ciências do Mar (LABOMAR), Av. Abolição, 3207, Meireles, Fortaleza, Ceará, Brazil. \\ E-mail: Souza_1_p@yahoo.com.br \\ ${ }^{2}$ Department of Biology, Federal University of Ceará, Âvenida Mister Hull 2977, Campus do Pici: Bloco 909, CEP: \\ 60455-760, Fortaleza, Ceará, Brazil.
}

\begin{abstract}
SUMMARY: The present study describes the morphology of the female reproductive system and the development of the germ cells of the crab Goniopsis cruentata. Specimens were collected monthly from the mangrove of the Ceará River (Brazil) for study of the reproductive system. The ovarian lobes unite near the middle of the cephalothorax and extend to the third abdominal segment. The ovaries connect to spermathecae draining into a short oviduct. Microscopically, four types of germ cells were identified. Four stages of ovary development were defined based on macroscopic and microscopic features. The association of ovary development stages with biometric measures shows that ovaries of females with triangular abdomens and a carapace width $(\mathrm{CW})$ of $21.0-29.3 \mathrm{~mm}$ were in the previtellogenic stage, while those of females with rounded abdomens and a $\mathrm{CW}$ of $26.4-46.1 \mathrm{~mm}$ varied with regard to maturity, the majority being late-stage vitellogenic or mature. The organisation of the female reproductive system of $G$. cruentata is similar to that of most other brachyurans, except for the extension of the ovaries to the abdomen.
\end{abstract}

Keywords: reproduction, Brachyura, oogenesis, mangrove.

RESUMEN: Morfología del SISTEMA REPRODUCTIVO de LAS HEMBRAS DEL CANGREJO ROJO DE MANGLE (GONIOPSIS CRUENTATA LATREILlE, I 803). - El presente estudio describe la morfología del sistema reproductivo femenino y el desarrollo de las células germinativas del cangrejo Goniopsis cruentata. Los ejemplares estudiados fueron recolectados mensualmente en un manglar del Río Ceará (Brasil). En plena madurez, los lóbulos del ovario se unen cerca del centro del cefalotórax y se extienden hasta el tercer segmento abdominal. Los ovarios se conectan a la espermateca a través de un pequeño oviducto. Microscópicamente, cuatro tipos de células germinativas fueron identificadas. Cuatro estadios de desarrollo ovárico fueron definidos en base a características macroscópicas y microscópicas. La asociación del desarrollo de los estadios de desarrollo ovárico con medidas biométricas muestra que los ovarios de las hembras con abdómenes de forma triangular y talla comprendida entre 21-29.3 mm de anchura de cefalotórax se encuentran en el estadio pre-vitelogénico, mientras que los ovarios de hembras con abdómenes redondeados y tallas comprendidas entre 26.4-46.1 mm varían en relación a su grado de desarrollo, la mayoría perteneciendo al estadio vitelogénico tardío o maduro. La organización del sistema reproductivo femenino de G. cruentata es similar al de la mayoría de otros cangrejos braquiuros, excepto por la extensión de los ovarios al abdomen.

Palabras clave: reproducción, Brachyura, oogénesis, manglar.

\section{INTRODUCTION}

Decapod crustacean gonads are partly or completely connected, paired and typically elongated organs located in the dorsal part of the body (Brusca and Brusca, 1990). The reproductive system of the female consists of a pair of ovaries, a pair of oviducts and, in some groups, a pair of spermathecae (Krol et al., 1992). Crab ovary development stages are usually determined based on the macroscopic features 
of the gonads, as reported for Araneaus cribrarius (Pinheiro and Fransozo, 1998), Hepatus pudibundus (Reigada and Negreiros-Fransozo, 2000), Chasmagnathus granulatus (Ituarte et al., 2004) and Goniopsis cruentata (Cobo and Fransozo, 1998a; 2005; Moura and Coelho, 2004). Microscopic features are rarely used for the purpose of classification. Mota-Alves (1975) and Santana (2002) used macroscopic features and histological analyses for the classification of the ovary development stages of the mangrove crab, Ucides cordatus.

The red-clawed mangrove tree crab (G. cruenta$t a)$ is found in the tropical waters of both the western Atlantic (Bermudas, Gulf of Mexico, the Antilles, the Guianas and Brazil from Pará to Santa Catarina, including Fernando de Noronha) and the eastern Atlantic (from Senegal to Angola) (Melo, 1996). In spite of its extensive distribution, few studies on the species' reproductive biology have been published in Brazil. Exceptions include studies from Pernambuco and São Paulo on physiological sexual maturity (Moura and Coelho, 2004; Cobo and Fransozo, 2005), fecundity (Cobo and Fransozo, 1997; Moura and Coelho, 2003), reproductive period (Cobo and Fransozo, 1998a) and spawning period (Cobo and Fransozo, 2003).

A description of the morphology of the male reproductive system of $G$. cruentata was published by Garcia and Silva (2006) based on specimens from the mangrove of the Ceará River (Caucaia, Ceará, Brazil). The present study aims to describe the structure of the female reproductive system, discuss the process of germ cell development and characterize the stages of ovarian development in relation to biometrical data and abdominal shape in G. cruentata.

\section{MATERIALS AND METHODS}

Ten female specimens of $G$. cruentata were collected monthly from the mangrove of the Ceará River (Caucaia, Ceará, Brazil) between October 2004 and October 2005. The animals were taken to a laboratory and cold-anesthetised and the carapace width (CW) and abdominal width (AW) were measured with a precision calliper $(0.1 \mathrm{~mm})$. After egg-bearing condition had been recorded, the reproductive system was exposed and the ovaries were examined for colour, consistency, volume and extension. Fragments of ovary were fixed in Bouin aqueous solution for 6 hours. Subsequently, the fragments were submit- ted to dehydration in a graded series of alcohol for infiltration and embedding in paraffin, or in historesin for thinner microtome sections. Histological sections measuring $5 \mu \mathrm{m}$ were submitted to staining with Gomori's trichrome (adapted from Tolosa et al., 2003) and the periodic acid-Schiff (PAS) reaction method (adapted from Junqueira and Junqueira, 1983) for the identification of glycoproteins, or with Ponceau xylidine (adapted from Mello and Vidal, 1980) and bromophenol blue (adapted from Pearse, 1960) for total protein. Macroscopic and microscopic aspects of the gonads, including the frequency of germ cells per microscope field and their organisation in the stroma, were used to determine the development stage of the ovary. Biometrical data and abdominal shapes were associated with ovary development stages.

\section{RESULTS}

A total of 120 females were examined, 23 of which were egg-bearing. Carapace width ranged from 21.0 to $46.1 \mathrm{~mm}$ for the whole group, and from 27.2 to $46.1 \mathrm{~mm}$ for egg-bearing individuals. The latter were observed in the months of March through August 2005, but were most frequent in April (80\%), May (60\%) and June (60\%).

The sexual dimorphism of $G$. cruentata is evident in the morphology of the abdomen, the number and position of the pleopods, the position of the gonopores and the size of the chelipeds. Some overlapping was observed with regard to abdomen shape and carapace width. Thus, among the specimens collected for this study, females with triangular abdomens had carapaces measuring 21.0-27.6 mm (but could be distinguished from males by the position of the gonopores), females with abdomens of the transitional type though not extending to the coxae of the pereiopods had carapaces measuring 23.6-29.3 $\mathrm{mm}$, and females with rounded abdomens with the extremities reaching the coxae of the pereiopods had carapaces measuring 26.4-46.1 mm.

\section{Anatomy of the female reproductive system}

The female reproductive system of $G$. cruentata consists of a pair of ovaries, a pair of oviducts and a pair of spermathecae. The ovaries are elongated organs located dorsally in the cephalothorax and interconnected only by a short transversal expansion posteriorly to the stomach and ventrally to the heart. 


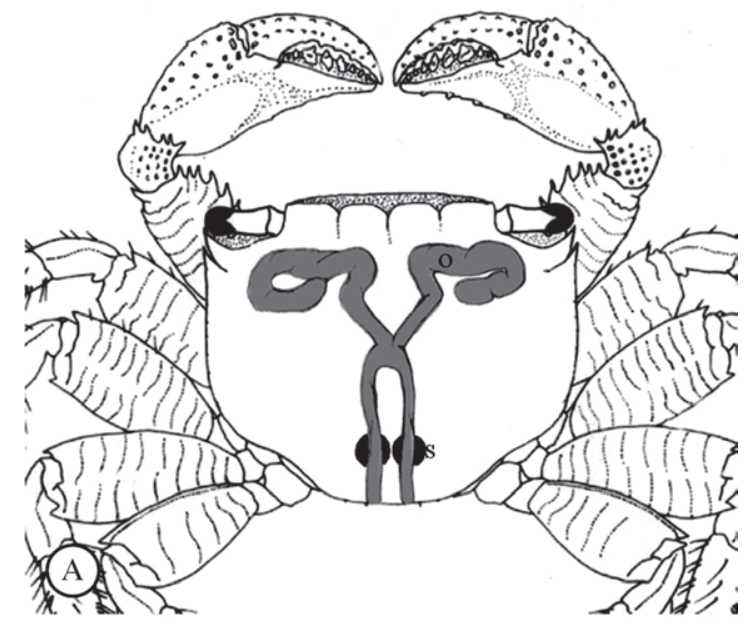

(B)

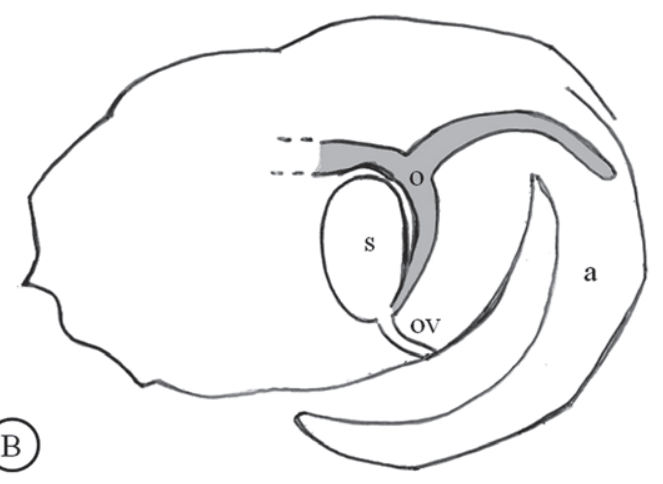

FIG. 1. - Anatomy of the female reproductive system of Goniopsis cruentata. A, schematic illustration showing only of female reproductive system showing ovaries (o) and spermathecae (s); B, sagittal section showing ovary (o), spermatheca (s) and oviduct (ov). Abdomen (a).
The ovaries extend posteriorly from the transversal expansion in the form of two parallel lobes positioned laterally to the mid-digestive tract. Depending on the stage of maturation, the posterior lobes may extend as far as the third abdominal segment (Fig. 1).

Around the middle of each posterior lobe an extension is seen projecting ventrally and connecting to the underside of the spermathecae. The spermathecae are spherical or ovoid sacs below the middle intestine, filled with a thick, milky liquid. The walls of the organ are thin, whitish and easily disrupted with the tweezers. Ventrally the spermathecae are coupled to a pair of short, thin and translucent oviducts which open onto the sternite of the sixth thoracic segment through an operculated pore called the gonopore.

The gonads vary in colour, shape, consistency and volume as the female matures. The colouring changes from white through orange to dark brown. White-coloured ovaries are cylindrical, slender and flaccid and extend to the first abdominal segment. Orange-coloured gonads are likewise cylindrical and slightly compressed dorsoventrally, but are firmer to the touch and reach the second or third abdominal segment. Dark brown ovaries are considerably larger and compressed dorsoventrally; the anterior lobes cover the entire hepatopancreas, while the posterior lobes may extend as far as the extremity of the third abdominal segment (Table 1).

TABLE 1. - Aspects of the ovary development stages of Goniopsis cruentata. Ovary (ov). Histological sections show types of germinative cells predominant in each stage (oo, oogonia; po, previtellogenic oocytes; ev, early-stage vitellogenesis; vo, late-stage vitellogenesis) and empty space (e) present in post-spawning ovaries.

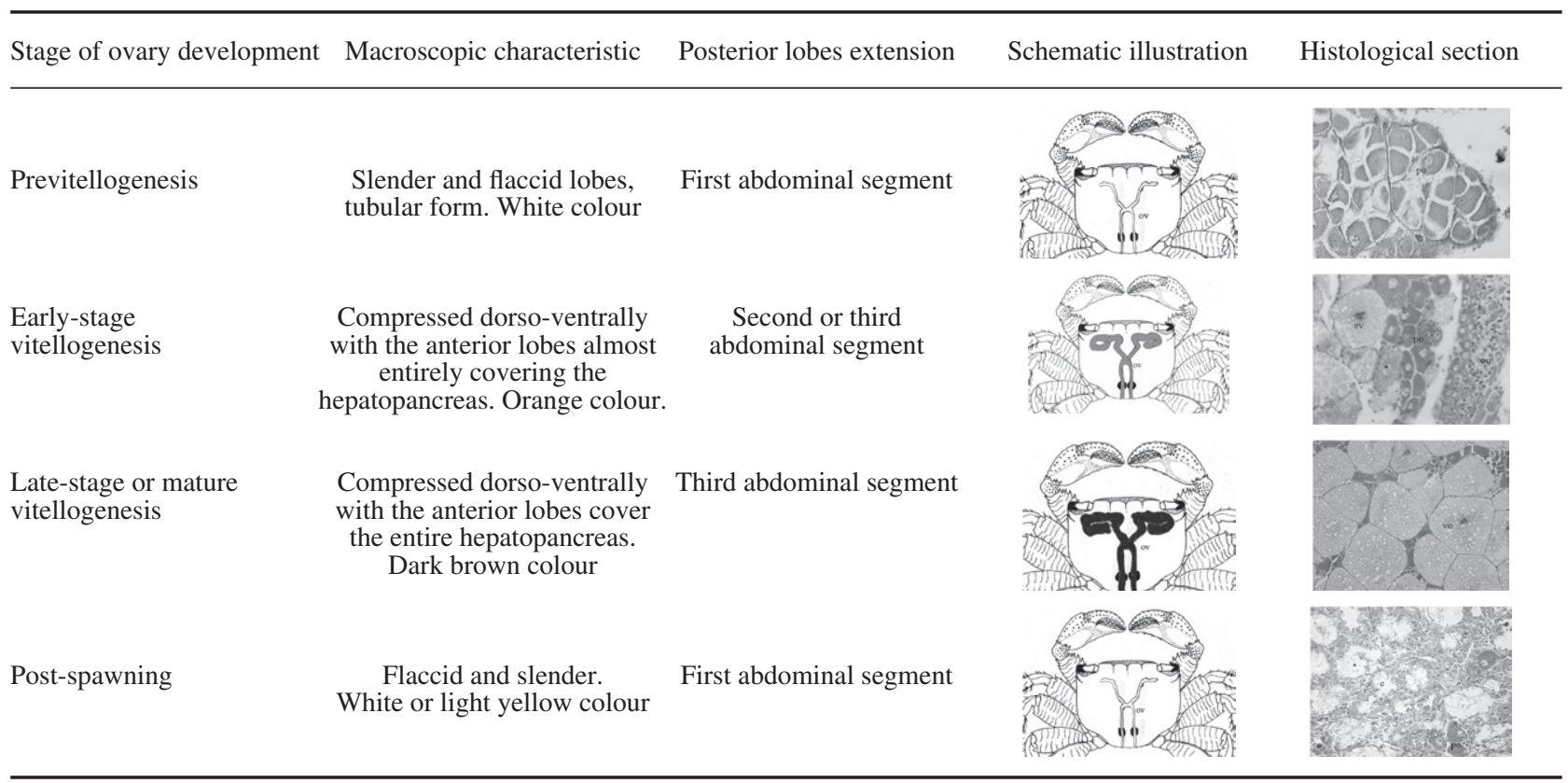



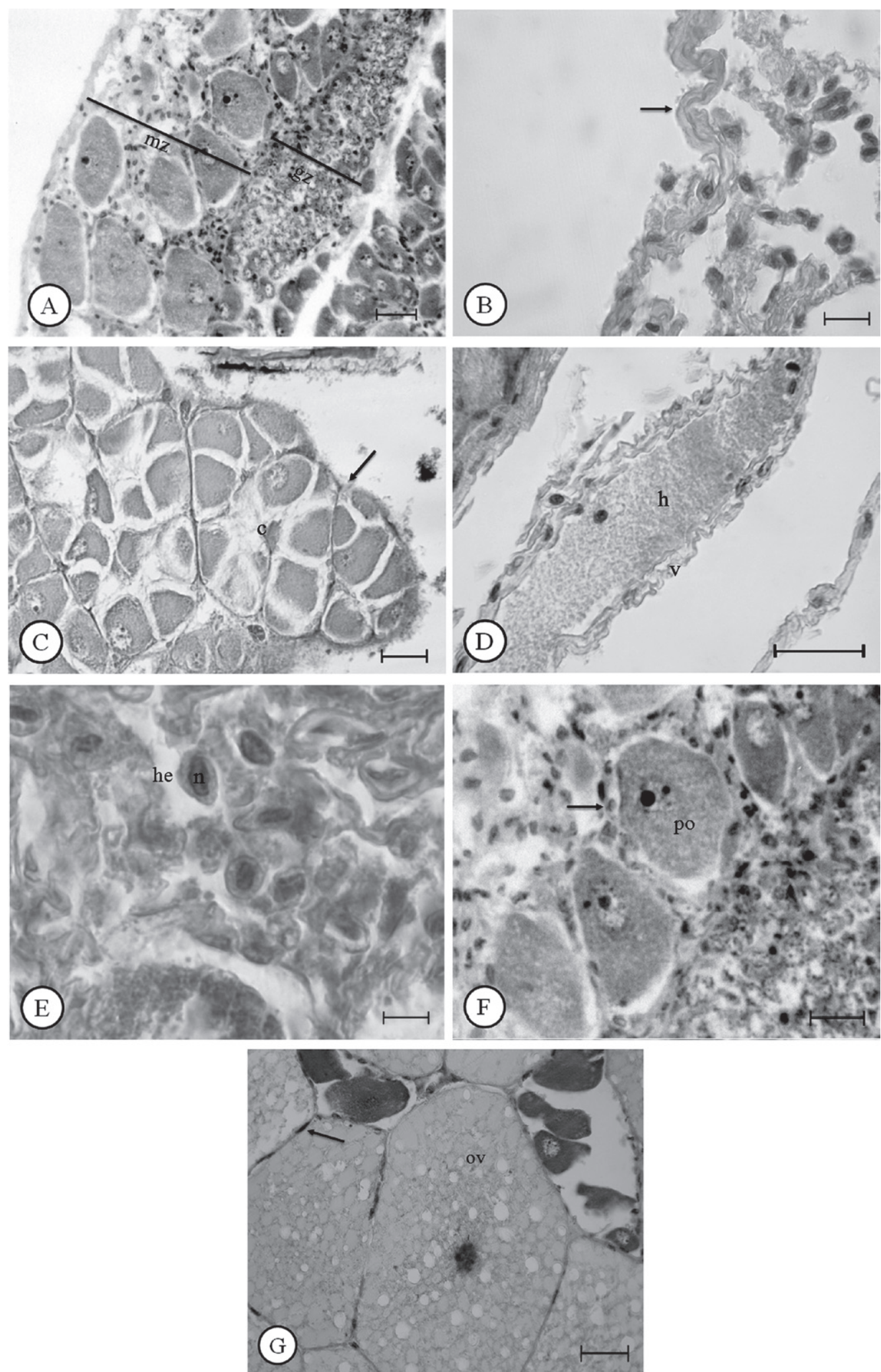

FIG. 2. - Photomicrograph of the somatic components of the ovary of Goniopsis cruentata stained with Gomori's trichrome. A, longitudinal section of ovary - germinative zone (gz); maturation zone (mz). Scale: $25 \mu \mathrm{m}$. B, external lining of ovary after spawning (arrow) with wavy appearance characteristic of the stage. Scale: $50 \mu \mathrm{m}$. C, previtellogenic ovary - periodic invaginations (arrow) in the lining in which cysts (c) are formed. Scale: $50 \mu \mathrm{m}$. D, hemal vessel (v) in ovary after spawning. Hemolymph (h). Scale: $30 \mu \mathrm{m}$. E, hemocytes (he). Nucleus of hemocytes (n). Scale: $4 \mu \mathrm{m}$. F, follicular cells (arrow) around previtellogenic oocytes (po). Scale: $30 \mu \mathrm{m}$. G, follicular cells (arrow) in squamous form associated with late-stage oocytes (ov). Scale: $50 \mu \mathrm{m}$. 


\section{Histological description of the ovaries}

The histological study provided information on the germinative and somatic components of the ovaries as well as on the relation between maturity and the organisation of these components.

The ovary of $G$. cruentata may be divided into two regions: the germinative (or proliferative) zone and the maturation zone (Fig. 2A). In the former, the germ cells undergo mitosis and initiate their development. Distally, in the latter, the growing germ cells go through the stages of vitellogenesis. The ovary of G. cruentata features no lumen.

The somatic components include the lining of the ovary, hemal vessels and sinuses, hemocytes, oocytes, follicular cells and fibrous material, the latter constituting the ovarian stroma.

The ovaries are lined with a layer of fibrous material containing cells with light-coloured immature cytoplasm and nuclei shown to be basophilic when submitted to staining with Gomori's trichrome. In the early stages of ovarian maturation, periodical invaginations in the lining give rise to cysts in which the germ cells develop (Fig. 2C). As the oocytes increase in volume and number in the ovaries, the lining changes appearance from wavy to distended and the cells assume the squamous form. After spawning, the lining becomes once again wavy in appearance and the cells turn ovoid (Fig. 2B).

The follicular cells, with their flattened and barely visible cytoplasm, are found throughout the ovaries, including the central germinative zone where they appear as scattered and unclustered. However, in the maturation zone the follicular cells start organising irregularly around the germ cells until they form a single layer of flattened cells with which the germ cells remain closely associated during the later stages of maturation (Fig. 2F and 2G).

The hemal vessels are lined by a thin and wavy membrane and contain a granular substance, the hemolymph (Fig. 2D). The membrane is stained dark green with Gomori's trichrome and reacts intensely to bromophenol blue or xylidine. The hemal sinuses appear as spaces filled with hemolymph between the ovary fibres. Both vessels and sinuses are most easily observed in the early stages of maturation and after spawning. The hemolymph contains spherical or ovoid cells, the hemocytes, which may also be seen in vessels and in the ovarian stroma (Fig. 2E). The nuclei of the hemocytes have an irregular shape and the cytoplasm is weakly basophilic, and stain- ing with bromophenol blue, xylidine and PAS elicits almost no response.

The germinative components are represented by germ cells at different stages of maturation, as determined by size, form, location in gonadal sections and response to dyes. Four categories of germ cells were identified:

Oogonia: Small germ cells measuring $10 \mu \mathrm{m}$ on average, oogonia are characteristically spherical with a small amount of cytoplasm in the form of a slender band encircling the nucleus. The nuclei of oogonia appear more developed than the cytoplasm, the chromatin is condensed especially at the periphery and in the centre of the nucleus, and no nucleoli are seen. The presence of groups of oogonia with highly condensed chromatin possibly indicates early mitosis (Fig. 3A). The oogonia are shown to be weakly basophilic when submitted to staining with Gomori's trichrome, and react little to the other dyes tested. Follicular cells and oogonia do not appear to be associated.

Previtellogenic oocytes: Irregularly shaped cells measuring 20-80 $\mu \mathrm{m}$, previtellogenic oocytes have larger nuclei and more cytoplasm than oogonia. The cytoplasm becomes gradually less basophilic as it increases in volume, the chromatin of the nucleus becomes less condensed and two peripheral nucleoli may be seen in close contact with the inner surface of the nuclear envelope (Fig. 3B). The cytoplasm of the previtellogenic oocytes in the maturation zone is weakly stained with bromophenol and xylidine, but not with PAS.

Vitellogenic oocytes: Measuring 50-340 $\mu \mathrm{m}$, vitellogenic oocytes differ from previtellogenic oocytes mainly by the presence of vesicles in the cortical region of the cell. As the ovaries mature, these vesicles become more densely and evenly distributed in the cytoplasm, thus increasing the size of the oocyte. The cytoplasm, which is initially basophilic and granulated within, becomes gradually filled with colourless vesicles in the cortical region. As the oocytes grow, the cytoplasm and emerging vesicles in the cortical region tend to be become green when stained with Gomori's trichrome (Fig. 3D). As the vesicles from the cortical region accumulate in the centre of the oocyte, two zones become visible in the cytoplasm: a weakly basophilic region near the nucleus and a cortical area completely filled with colourless vesicles when stained with Gomori's trichrome (Fig. 3C). By the end of this stage, the vitellogenic oocytes 

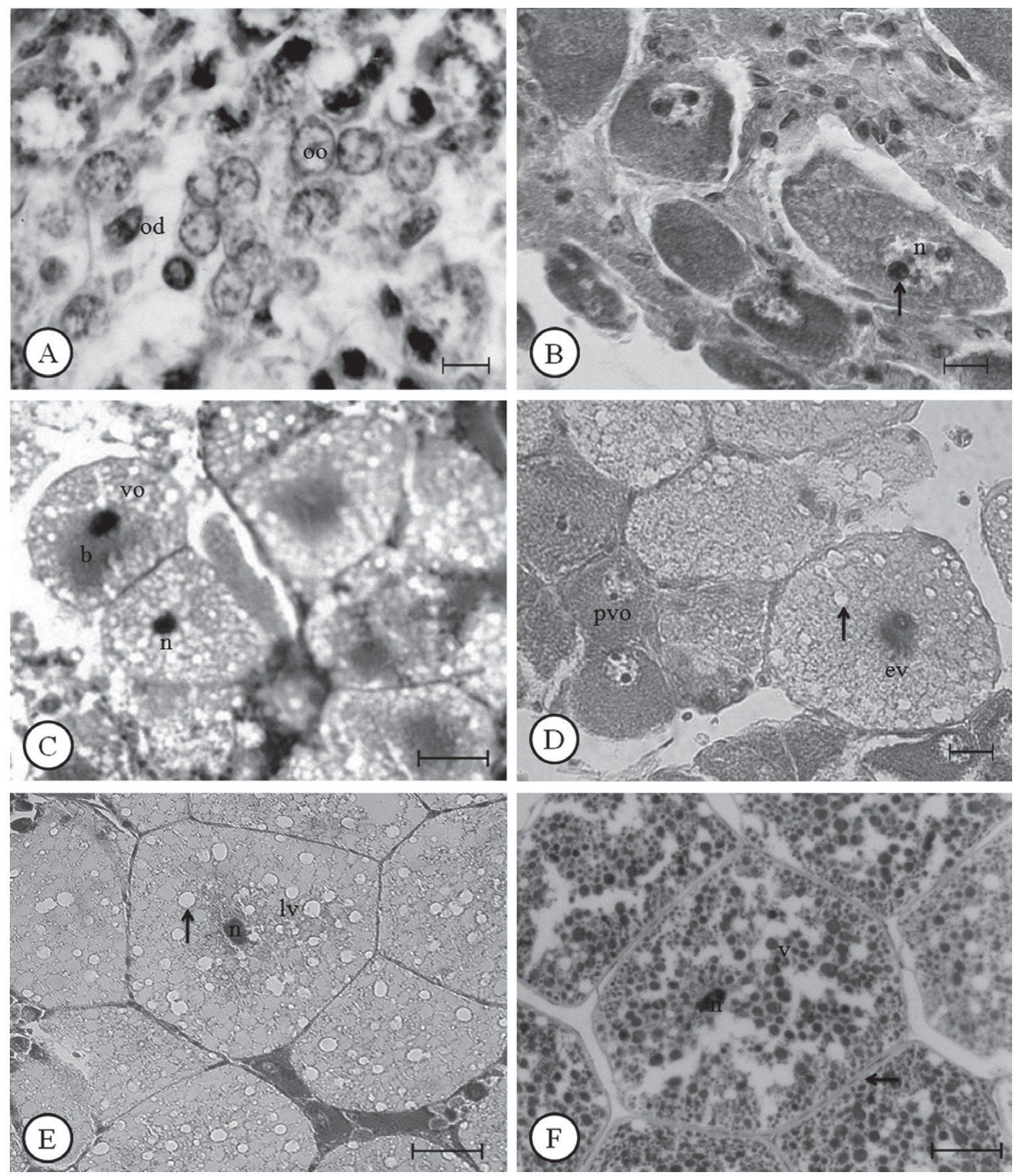

FIG. 3. - Photomicrograph of the germinative cells of Goniopsis cruentata stained with Gomori's trichrome showing germ cells at different development stages. A, oogonia (oo). Observe compacted chromatin, indicating possible cell division (od). Scale: $10 \mu \mathrm{m}$. B, previtellogenic oocytes (pvo); nucleus (n); peripheral nucleoli (arrow). Scale: $15 \mu \mathrm{m}$. C, oocytes in vitellogenesis (vo). Basophilic region (b) near the nucleus (n). Scale: $100 \mu \mathrm{m}$. D, oocyte in early-stage vitellogenesis (ev); vitelline vesicles (arrow). Previtellogenic oocytes (pvo). Scale: 25 um. E, oocyte in late-stage vitellogenesis (lv). Nucleus (n). Scale: $50 \mu \mathrm{m}$. F, oocyte in late-stage vitellogenesis. Light green chorion (arrow). Nucleus (n). Scale: $60 \mu \mathrm{m}$.

undergo biochemical changes, as reflected by the change from light green to bright red when stained with Gomori's trichrome (Fig. 3F), and the cytoplasm is totally filled with vesicles. As long as the vesicles are stained green with Gomori's trichrome, they display a weak reaction to bromophenol blue, xylidine and PAS. However, once they turn bright red with Gomori's trichrome they also react more intensely to other dyes. At this point the cell nuclei have become centralised, irregularly shaped, strongly basophilic and smaller than during the previtellogenic stage. 
At a more advanced stage of vitellogenesis, a continuous and flattened band-the chorion-may be seen externally to the oocytes and below the follicular cells. While clearly visible in sections stained with PAS, the chorion is weakly stained with bromophenol blue and xylidine and stained light green with Gomori's trichrome (Fig. 3F).

Mature oocytes: The largest of the germ cells, mature oocytes are polyhedral and measure 250$410 \mu \mathrm{m}$. The cytoplasm is filled with vesicles stained red with Gomori's trichrome and colourless vesicles larger than those observed during earlier stages. The cytoplasm of mature oocytes react strongly to bromophenol blue, xylidine and PAS. The nucleus is not visible, probably because of its reduced size in relation to the cytoplasm and of the plane of histological section.

\section{Stages of ovary development}

Four stages of development were defined based on the microscopic and macroscopic characteristics of the ovary.

I. Previtellogenesis. The ovaries are little developed and feature slender lobes reaching no farther than the first abdominal segment. The flaccid and whitish or yellowish ovaries of this stage can be difficult to excise (Table 1). In longitudinal and transversal sections of the central germinative zone, oogonia may be seen undergoing division. Outside this zone only previtellogenic oocytes are observed, organised in periodic invaginations in the lining and forming cysts (Fig. 2C). At this point follicular cells start grouping around the oocytes.

II. Early-stage vitellogenesis. The ovary is orange-coloured and compressed dorso-ventrally with the anterior lobes almost entirely covering the hepatopancreas, while the posterior lobes extend to the second or third abdominal segment (Table 1). The germinative zone is observed microscopically to be compressed by the surrounding previtellogenic oocytes. At the periphery of the ovary, oocytes may be seen undergoing early vitellogenesis. Due to increase in volume, the vitellogenic oocytes eventually compress the periodical invaginations in the lining.

III. Late-stage or mature vitellogenesis. At this stage the ovaries are large and dark brown. The anterior lobes cover the entire hepatopancreas while the posterior lobes may extend as far as the end of the third abdominal segment (Table 1). Histologically, in late-stage vitellogenesis the ovaries are mostly filled with oocytes undergoing late-stage vitellogenesis, and very few previtellogenic oocytes are observed. Mature ovaries appear uniform and completely filled with mature oocytes in addition to a small number of late-stage vitellogenic oocytes. The germinative zone is difficult to see.

$I V$. Post-spawning. After spawning, the gonads become flaccid and white or light yellow, making them difficult to distinguish from previtellogenic gonads. Due to the release of mature oocytes, the ovaries become extremely flattened and now extend as far as the first abdominal segment (Table 1). Histologically, the ovaries may take on two distinct appearances. One of these is associated with a period of major disarray caused by the release of mature oocytes. At this stage, several previtellogenic oocytes and empty spaces are seen in the ovarian stroma, along with a considerable number of hemocytes, fibres and follicular cells. In our specimens, a few hemocytes associated with previtellogenic oocytes were also observed. Likewise, a number of oogonia in the germinative zone seem to be undergoing mitosis. Upon oocyte release, the ovarian lining assumes a distinctly wavy appearance. The second condition observed corresponds to the reorganisation of the ovaries accompanied by a significant decrease in the number of hemocytes and empty spaces. The follicular cells appear to cluster around the oocytes and the lining loses its wavy appearance.

\section{Ovary stages vs biometric data}

Females with a triangular abdomen reaching short of the coxae of the pereiopods (CW: 21.0-29.3 $\mathrm{mm}$ ) had previtellogenic ovaries without exception, while larger specimens with the abdomen extending as far as the coxae of the pereiopods (CW: 26.4-46.1 $\mathrm{mm}$ ) featured ovaries at varying stages, though most were late-stage vitellogenic or mature.

Thus, some overlapping is observed in the $\mathrm{CW}$ range of 26.4-29.3 $\mathrm{mm}$, in which some females feature a completely developed abdomen and are capable of producing fertilizable oocytes, while others feature a triangular abdomen and are capable of producing previtellogenic oocytes only (Table 2).

\section{DISCUSSION}

The shape of the abdomen of maturing females of $G$. cruentata changes from triangular to rounded 
TABLE 2. - Interrelation between ovary stages and abdomen shape in Goniopsis cruentata.

\begin{tabular}{|c|c|c|c|}
\hline Carapace width (cw) & Abdomen shape & Stagy of ovary development & Abdomen picture \\
\hline $21-27.6 \mathrm{~mm}$ & Triangular & Previtellogenesis & \\
\hline $23-29.3 \mathrm{~mm}$ & $\begin{array}{l}\text { Transitional type though } \\
\text { extending to the coxae } \\
\text { of the pereiopods }\end{array}$ & Previtellogenesis & \\
\hline $26.4-46.1 \mathrm{~mm}$ & $\begin{array}{l}\text { Rounded with the } \\
\text { extremities reaching the } \\
\text { coxae of the pereiopods }\end{array}$ & $\begin{array}{c}\text { Previtellogenesis; } \\
\text { early-stage vitellogenesis; } \\
\text { late stage or mature vitellogenesis; } \\
\text { post-spawning }\end{array}$ & \\
\hline
\end{tabular}

and eventually reaches the coxae of the pereiopods. Similar variations have been observed in brachyuran crabs such as Libinia emarginata (Hinsch, 1972) and Arenaeus cribrarius (Pinheiro and Franzoso, 1998), as well as in a study on G. cruentata classifying females into juvenile, prepuberal or adult (Cobo and Franzoso, 1998b).

The fact that all egg-bearing females displayed a rounded abdomen indicates that this modification is required for incubation. Thus, since incubation is characteristic of all Pleocyemata (Christoffersen, 1988), it is not unlikely that the widening of the abdomen may serve as an indicator of maturity in other species of the group.

\section{Anatomy of the female reproductive system and ovary development stages}

The paired gonads of the female $G$. cruentata are bridged by a tranversal commissure, as described by Adiyodi and Subramoniam (1983) and by Krol et al. (1992) for other decapod species. A similar structure has been reported for Panulirus spiny lobsters (Mota-Alves and Tomé, 1966; Silva and CruzLandim, 2006), for the spiny lobster Jasus frontalis (Elorza and Dupré, 2000), and for the brachyurans Libinia emarginata (Hinsch and Cone, 1969; Hinsch, 1972), Ucides cordatus (Mota-Alves, 1975; Santana, 2002), Callinectes sapidus (Johnson, 1980), Portunus sanguinolentus (Ryan, 1967) and Potamon dehaani (Ando and Makioka, 1999).

Decapod ovaries are generally located in the cephalothorax, with the exception of the anomurans, whose gonads are primarily located in the abdomen
(Kaestner, 1970). In G. cruentata the maturing gonads extend as far as the third abdominal segment, while brachyuran ovaries are restricted to the cephalothorax (Adiyodi and Subramoniam, 1983; Krol et al., 1992). In shrimps and lobsters, posterior lobes extend to the abdomen. In the shrimp species Macrobrachium acanthurus (Carvalho, 1981; Carvalho and Pereira, 1981) and the spiny lobster species Jasus frontalis (Elorza and Dupré, 2000) and Panulirus species (Mota-Alves and Tomé, 1966; Silva and Cruz-Landim, 2006), the ovaries reach the second abdominal segment. The posterior lobes do not reach the telson in Pleocyemata decapod crustaceans, while, in contrast, Dendrobranchiata have lobes extending to the telson.

In the present study, gonads of G. cruentata at different stages of maturity displayed differences in colouring from white to orange to dark brown, matching the findings of Cobo and Franzoso (1998a; 2005) for specimens collected on the coast of São Paulo, Brazil. According to Adiyodi and Subramoniam (1983), the colouring of the ovaries is the result of carotenoid pigments accumulated in the oocytes during vitellogenesis, protecting the embryo against solar radiation.

Four stages of ovary development were observed for G. cruentata: previtellogenesis, early-stage vitellogenesis, late-stage vitellogenesis or mature, and post-spawning. According to Silva and Cruz-Landim (2006), while the first stage is generally termed "immature" and the last stage is called "spawned" or "post-spawn", intermediate stages are assigned a confusing array of names, including "development", "inactive", "prematuration", "near-mature", "active", 
"mature" and "maturing". Some authors have proposed rather impractical ovary development staging systems subdividing primary stages into a number of smaller stages based on very slight morphological changes. The four-stage classification used in the present study accentuates the main morphological aspects presented by the developing gonads and would therefore be more suitable for routine use. A similar classification has been used for the crab species $U$. cordatus (Santana, 2002). Other authors have classified ovary development in $G$. cruentata based on macroscopic observation alone, as in a study published by Cobo and Fransozo (1998a) considering three maturation stages, and in studies by Moura and Coelho (2004) and by Cobo and Fransozo (2005) proposing a five-stage classification.

In the first (previtellogenic) stage of ovary development our specimens had mitotic oocytes in the central germinative zone and, outside this zone, only previtellogenic oocytes organised in cysts, matching findings for the shrimp species Macrobrachium acanthurus (Carvalho and Pereira, 1981); Macrobrachium amazonicum (Bragagnoli and Grotta, 1995), for which the stage was given as "immature"; and Artemesia longinaris (Dumont and d'Incao, 2004), for which the stage was described as "immature" or "previtellogenic", but differing from the crab Ucides cordatus (Mota-Alves, 1975), and the spiny lobsters Panulirus laevicauda (Mota-Alves and Tomé, 1966) and Panulirus argus (Mota and Tomé, 1965), which have only oogonia during the first stage of maturation.

Krol et al. (1992) described how some decapod species can store sperm in a modified section of the oviduct termed the "spermatheca". While the ovary of the portunid crab Callinectes sapidus is connected to the dorsum of the spermatheca (Johnson, 1980), in $G$. cruentata it adheres to the underside, suggesting that the structure may be a modified part of the oviduct. Depending on the species, the connection may consist of a short oviduct, as in the spider crab Chionoecetes opilio (Beninger et al., 1998), or of several oviducts, as in the freshwater potamonid crabs (Brandis et al., 1999).

The spermathecae of G. cruentata are filled with a thick, milk-coloured liquid. According to Adiyodi and Subramonian (1983), the secretions of crab spermathecae probably contribute to the maintenance of the spermatozoa. In fact, the spermatozoa of a single mating may be stored in the spermathecae for more than one spawning season.

\section{Histological characterisation of ovaries}

The central position of the germinative zone in the ovaries of $G$. cruentata resembles that of the brachyurans Portunus sanguinolentus (Ryan, 1967), Libinia emarginata (Hinsch and Cone, 1969), Ranina ranina (Minagawa et al., 1993), Chionoecetes opilio, Hyas coarctatus (Lanteigne et al., 1996), Ucides cordatus (Santana, 2002) and Maja brachydactyla (Rotllant et al., 2007), the caridean freshwater shrimps Macrobrachium acanthurus (Carvalho and Pereira, 1981; Carvalho, 1981) and Macrobrachium amazonicum (Chaves and Magalhães, 1993) and the spiny lobster Jasus frontalis (Elorza and Dupré, 2000). According to Adiyodi and Subramoniam (1983), while the location of the germinative zone varies considerably in decapods, it is primarily central in brachyurans. Examples of the germinative zone in outlying position are the peneid shrimp Litopenaeus setiferus and Litopenaeus stylirostris (King, 1948) and the hermit crab Clibanarius clibanarius (Varadarajan and Subramoniam, 1980).

No lumen-like central cavity was observed in the ovaries of G. cruentata, following the example of most decapods (Krol et al., 1992). However, a lumen may be seen in Ucides cordatus (Santana, 2002), Potamon dehaani (Ando and Makoika, 1999), Jasus frontalis (Elorza and Dupré, 2000) and in Panulirus spiny lobsters (Silva, 1999).

Most studies on decapod ovarian histology concentrate on germinative components, giving little or no attention to somatic components. In $G$. cruentata, the ovarian lining consists of a thin layer of fibrous connective tissue with associated cells. Similar findings have been reported by Johnson (1980) for Callinectes sapidus and by Silva and Cruz-Landim (2006) for Panulirus spiny lobsters. In Jasus frontalis (Elorza and Dupré, 2000) the lining features two layers, an external layer of connective tissue and an internal layer of muscle tissue. Despite the fact that few crustacean ovaries contain muscle tissue (Adiyodi and Subramoniam, 1983), Elorza and Dupré (2000) report that the ovulation of $J$. frontalis occurs with the aid of contractions of muscles in the ovary wall. Species with no muscles in the ovaries probably spawn by contracting the abdominal and cephalothoracic muscles adjacent to the ovaries (Adiyodi and Subramoniam, 1983). This is very likely also the case of $G$. cruentata since no muscles have been observed in the ovaries of this species. 
In our specimens no change was observed in the thickness of the ovary lining regardless of the germ cell development stage, unlike findings reported for Panulirus spiny lobsters (Silva and Cruz-Landim, 2006). The organisation of the ovaries into subunits (called cysts, lobes or nodules, depending on the study) observed for $G$. cruentata has also been reported for the brachyurans Callinectes sapidus (Johnson, 1980), Portunus sanguinolentus (Ryan, 1967) and Ucides cordatus (Mota-Alves, 1975; Santana, 2002), for the palemonid Macrobrachium amazonicum (Bragagnoli and Grotta, 1995) and for the spiny lobsters Panulirus laevicauda (Mota-Alves and Tomé, 1996; Silva and Cruz-Landim, 2006), Panulirus argus and Panulirus echinatus (Silva and Cruz-Landim, 2006). Elorza and Dupré (2000) consider these invaginations a sort of internal ovarian skeleton responsible for organising the structural components of the organ.

The cells associated with the ovary lining in $G$. cruentata are possibly fibre-producing fibroblasts or myofibroblasts. In an ultrastructural description of Panulirus ovaries, Silva (1999) characterised similar cells as myofibroblasts. According to Ross et al. (1993), myofibroblasts not only produce the fibres of the connective tissue, but also contain contractile elements involved in the process of ovulation.

Hemocytes were observed mostly in ovaries following spawning. In a study on the deep-sea crab Chaceon fenneri, Hinsch (1992) hypothesised that these cells are associated with oocyte resorption, possibly by secreting hydrolitic enzymes promoting oocyte degeneration. Adiyodi and Subramoniam (1983) believe hemocytes may act as phagocytes, ingesting residues present in the ovaries.

The association between follicular cells and oocytes was observed at all ovary development stages. At first the follicular cells cluster irregularly around previtellogenic oocytes, but subsequently they make up a single layer encircling mature and vitellogenic oocytes. The process, which is called folliculogenesis in a study by Adiyodi and Subramoniam (1983), has been observed for the brachyurans Portunus sanguinolentus (Ryan, 1967), Callinectes sapidus (Johnson, 1980), Cancer pagurus (Eurenius, 1973) and Ucides cordatus (Santana, 2002), as well as for Panulirus spiny lobsters (Silva and Cruz-Landin, 2006).

Ryan (1967) and Silva (1999) have hypothesised, respectively, that the follicular cells of Portunus sanguinolentus and of Panulirus spiny lobsters are responsible for synthesising the components of the chorion. In $G$. cruentata, since the chorion is only observed after the follicular cells have formed a single layer around the oocytes, it seems likely that the follicular cells contribute to the formation of the chorion.

In our study, hemal sinuses and vessels were mostly observed in post-spawn ovaries or during the early stages of maturation, probably because they become compressed between vitellogenic and mature oocytes, and thus invisible, during the later stages. In an earlier study, the hemolymph of immature Panulirus spiny lobster ovaries, or of ovaries undergoing resorption, stained intensely for proteins and carbohydrates (Silva, 1999). This, according to the author, may be due to increased consumption of these substances by vitellus-forming germ cells during the previtellogenic and mature stages and to their elimination by oocytes remaining after ovulation.

The histological examination of the ovaries of G. cruentata revealed four types of germ cells: oogonia, previtellogenic oocytes, vitellogenic oocytes and mature oocytes. The description of cellular stages agrees with the characteristics described by Adiyodi and Subramonian (1983). A similar characterisation was adopted for the brachyurans $U c a$ rapax (Castiglioni et al., 2007), Ucides cordatus (Santana, 2002), and Chasmagnathus granulata (López et al., 1997) and for Panulirus spiny lobsters (Silva, 1999). Germ cells are classified according to a range of criteria, such as cell diameter and nucleus appearance (Mota and Tomé, 1965) and degree of vitellogenesis (Kulkarni et al.,1991). In the present study the classification was based on degree of vitellogenesis.

According to Silva (1999), the presence of highly developed nuclei, as observed in G. cruentata, indicates that the nuclear components are ready for vitellogenesis. In crustaceans, this type of cell is only found in the germinative zone, where it is produced by mitosis throughout the egg-bearing life of the female (Adiyodi and Subramoniam, 1983; Krol et al., 1992). Groups of oogonia with compacted chromatin, possibly undergoing mitosis, were observed in the specimens of G. cruentata collected for this study. According to Adiyodi and Subramoniam (1983), the rapid succession of mitotic stages in oogonia makes them difficult to observe. In fact, although mitotic oogonia were identified in our specimens, the specific stages could not be determined. 
The previtellogenic oocytes of G. cruentata may be described as cells with strongly basophilic cytoplasm, relatively uncondensed nuclear chromatin and two peripheral nucleoli in close contact with the internal surface of the nuclear envelope. Chaves and Magalhães (1993) believe the high level of basophilia observed in the previtellogenic oocytes of Macrobrachium acanthurus are due to enrichment of the cytoplasm with ribosomes attached to the rough endoplasmic reticulum. Beams and Kessel (1962) and Eurenius (1973) found a well-developed rough endoplasmic reticulum in the previtellogenic oocytes of the crayfish Cambarus virilis and the crab species Cancer pagurus, respectively. Kessel (1968) observed a great number of ribosomes in early-stage germ cells of lobsters of the genera Homarus and Panulirus. According to Krol et al. (1992), decapod previtellogenesis is characterised by increased activity in the various cytoplasmic organelles. The proximity of the nucleoli to the nuclear envelope suggests that material may be transferred to the cytoplasm of the oocytes, a phenomenon observed by Hinsch and Cone (1969) for Libinia emarginata, by Kessel and Beams (1968) for Orconectes virilis and by Silva (1999) for Panulirus lobsters. The displacement of nuclear material, as observed for $G$. cruentata, may entail the transfer of RNA or mRNA from the nucleus to the cytoplasm (Adiyodi and Subramoniam, 1983).

In Callinectes sapidus (Johnson, 1980), Ucides cordatus (Santana, 2002) and in Panulirus (Silva, 1999) the previtellogenic oocytes have a large peripheral cytoplasmic inclusion body called the perinuclear yolk-nucleus complex; this, however, was not observed in the present study for G. cruentata. According to Silva (1999), the presence of this component indicates that the oocytes are ready for vitellogenesis. The vitellus may consist of lipids, glycogen and protein-rich inclusions associated with lipids and polysaccharides, the latter enveloped by a membrane (Ganion and Kessel, 1972). According to Adiyodi and Subramoniam (1983), the decapod vitellus consists mostly of proteins and lipids, and during embryogenesis lipids, as well as proteins used as basic structural material in the synthesis of new tissue components, act as an energy reserve. Carbohydrates, however, are used in chitin formation (Travis, 1955).

Vitellogenesis is divided into two successive phases that clearly differentiate the oocyte growth period. Primary vitellogenesis is characterised by endogen protein yolk accumulation, while in secondary vitellogenesis extracellular protein substances are incorporated through pinocytosis. This pattern was described in Homarus americanus (Kessel, 1968), Libinia emarginata (Hinsch and Cone, 1969), Cancer pagurus (Eurenius, 1973) and Maja brachydactyla (Rotllant et al., 2007). In a light microscopy study of the vitellogenesis of Ucides cordatus, Santana (2002) observed a large number of small, spherical vesicles developing adjacent to the inner surface of the membrane. The author characterised the process as the possible incorporation of extracellular material by the cell for the purpose of vitellogenesis. The characteristics observed for previtellogenic oocytes in G. cruentata, such as the presence of nucleoli in close contact with the nuclear envelope (indicating the transfer of nuclear material to the cytoplasm) and the high degree of basophilia in the cytoplasm (indicating the accumulation of acid structures like RNA and ribosomes, and consequent development of rough endoplasmic reticulum), suggest endogen yolk accumulation. It was not possible to determine the occurrence of incorporation of extracellular substances in this research. For such intention, studies with electronic microscopy should be accomplished.

Histochemical analyses have shown that the vesicles contain proteins, glycoproteins and lipids. Bromophenol blue and xylidine were used to stain vesicles for proteins, while glycoproteins were detected with PAS. Lipid components were detected by the negative response to these dyes of some of the cytoplasmic vesicles. These were larger and more numerous in mature oocytes.

The present study suggests that late-stage oocytes undergo biochemical changes, as indicated by the change from light green to bright red in vesicles stained with Gomori's trichrome. In a study of the ultrastructure of the vitellogenic oocytes of Cancer pagurus, Eurenius (1973) observed that the yolk protein, a precursor to the actual yolk through a series of biochemical changes, is initially synthesised in the rough endoplasmic reticulum. Kessel (1968) reported similar findings for Homarus and Panulirus lobsters, but added that the yolk in the vesicles becomes more concentrated after the biochemical changes. In G. cruentata, when the vitelline vesicles are stained bright red with Gomori's trichrome, they also react intensely to bromophenol blue and PAS, indicating an increase in, respectively, the concentration and the quantity of proteins and glycoproteins. 


\section{Ovary stages vs biometric data}

In our sample, the smallest females of G. cruentata with developed ovaries had a CW of $26.4 \mathrm{~mm}$, while egg-bearing females measured at least 27.2 mm. According to Conan et al. (2001), crustaceans may be considered physiologically mature when they are capable of producing viable gametes. Thus, sexual maturity for female specimens of G. cruentata collected from the Ceará River in Northeastern Brazil seems to be attained when the CW is approximately $26.4 \mathrm{~mm}$. These findings match observations for specimens sampled in Pernambuco (CW: 28 $\mathrm{mm}$ ) (Moura and Coelho, 2004), while individuals collected for a study in São Paulo were mature at only $21.0 \mathrm{~mm}$ (Cobo and Fransozo, 2005). On the other hand, this is not surprising since the size at sexual maturity has been observed to vary according to geographical distribution (Adiyodi, 1988).

Leite (2005) associates the onset of functional sexual maturity with the attainment of the size at which crustaceans are able to mate as a consequence of morphometric changes in structures related to secondary sexual characteristics. In the present study, all specimens of $G$. cruentata featuring triangular abdomens, or abdomens not reaching the coxae of the pereiopods (CW: 21-29.3 $\mathrm{mm}$ ), had previtellogenic ovaries, while all late-stage and mature females featured rounded abdomens reaching the coxae of the pereiopods. This resembles findings for females of Libinia emarginata (Hinsch, 1972) showing that individuals with triangular abdomens are sexually immature and individuals with rounded abdomens are late-stage or mature. Thus, it seems that physiological maturity and functional sexual maturity are synchronous in G. cruentata, and it may be suggested that the presence of a rounded abdomen with the extremities reaching the coxae of the pereiopods is an indicator of both physiological and functional sexual maturity in females of $G$. cruentata.

\section{ACKNOWLEDGEMENTS}

The authors thank Biologist Danielle Sequeira Garcez for reading the resumen in spanish.

\section{REFERENCES}

Adiyodi, R.G. - 1998. Reproduction and development. In: W.W. Burggren and B.R. Mchanon. Biology of the Land Crabs, pp. 139-185. Cambridge University.
Adiyodi, R.G. and T. Subramoniam. - 1983. Arthropoda Crustacea. In: K.G. Adiyodi and R.G. Adiyodi. Reproductive Biology of Invertebrates, pp. 443-495, v. 1, John Wiley and Sons Ltd.

Ando. H. and T. Makioka. - 1999. Structure of the ovary and mode of Oogenesis in a Freshwater crab Potamon dehaani. J. Morphol., 239: 107-144.

Beams, H.W. and R. Kessel. - 1962, Intracisternal granules of the endoplasmatic reticulum in the crayfish oocyte. J. Cell. Biol., 13: $158-162$.

Beninger. P.G., R.W. Elner, T.P. Foyle and P.H. Odense. - 1998. Functional anatomy of the male reproductive system and female spermatheca in the snow crab Chionoecetes opilio (O. Fabricius) (Decapoda: Majidae) and a hypothesis for fertilization. $J$. Crustac. Biol., 8(3): 322-332.

Bragagnoli, G. and M. Grotta. - 1995. Reprodução do camarão de água-doce Macrobrachium amazonicum do açude Epitácio Pessoa, Bosqueirão (PB), Brasil. Parte I: Ciclo Sexual. Rev. Nordestina Biol., 10(2): 141-154.

Brandis, D., Storch, V. and M. Turkay. - 1999. Morphology and function of the copulatory system in freshwater crabs of the genus Potamon. J. Morphol. , 239: 157-166.

Brusca, R.C. and G.J. Brusca - 1990. Invertebrates. Massachusetts: Sunderland.

Carvalho, H.A. - 1981. Morfologia do aparelho reprodutor de Macrobrachium acanthurus (Wiegmann, 1936) (Crustacea, Decapoda, Palaemonidae) Parte II: feminino. Trab. Oceanogr. Univ. Fed. Pe., 16: 249-264.

Carvalho, H.A. and M.C.G. Pereira. - 1981. Descrição dos estágios ovarianos de Macrobrachium acanthurus (Weigman, 1936) (Crustacea, Palaemonidae) durante o ciclo reprodutivo. Ciência e Cultura, 33(10): 1353-1359.

Castiglioni, D.S., M.L. Negreiros-Fransozo, L.S.L. Greco, A.F. Silveira and S.O. Silveira. - 2007. Gonad development in females of fiddler crab Uca rapax (Crustacea, Brachyura, Ocypodidae) using macro and microscopic techniques. Iheringia, Sér. Zool., 97(4): 505-510.

Chaves, T. de. C. and C.O. Magalhães. - 1993. Desenvolvimento ovocitário em Macrobrachium acanthurus (Heller,1962) (Crustacea: Decapoda: Palaemonidae), camarão dulcícola da região amazônica. Acta Amazon., 23 (1): 17-23.

Christoffersen, M.L. - 1998. Phylogenetic systematica of Eucarida (Crustacea Malacostraca). Rev. Bras. Zool., 5(2): 325-351.

Cobo, V.J. and A. Fransozo. - 1997. Biologia do caranguejo grapsídeo Goniopsis cruentata (Latreille, 1803) (Crustácea, Decapoda). I - Fecundidade. VII Colacmar - Congres. Lat. Amer. Ciênc. Mar. 1997. Santos, SP.

Cobo, V.J. and A. Fransozo. - 1998a. Fecundity and reproduction period of the red mangrove crab Goniopsis cruentata (Brachyura, Grapsidae), São Paulo state, Brazil. Proc. $4^{\text {th }}$ Int. Crustac. Cong. p. 20-24.

Cobo, V.J. and A. Fransozo. - 1998b. Relative growth of Goniopsis cruentata (Crustacea, Brachyura, Grapsidae), on the Ubatuba region, São Paulo, Brazil. Iheringia, Sér. Zool., 84: 21-28.

Cobo, J.C. and A. Fransozo. - 2003. External factors determining breeding season in the red mangrove crab Goniopsis cruentata (Latreille) (Crustacea, Brachyura, Grapsidae) on the São Paulo State northern cost, Brazil. Rev. Bras. Zool., 20(2): 213-217.

Cobo, V.J. and A. Fransozo. - 2005. Physiological maturity and relationships of growth and reproduction in the red mangrove crab Goniopsis cruentata (Latreille) (Brachyura, Grapsidae) on the coast of São Paulo, Brazil. Rev. Bras. Zool., 22(1): 219-223.

Dumont, L.F.C. and F. D'Incao. - 2004. Estágios de desenvolvimento gonadal de fêmeas do camarão-barba-ruça (Artemesia longinaris - Decapoda: Palaemonidae), Iheringia, Ser. Zool., 94(4): 389-393.

Elorza, A. and E. Dupré. - 2000. Arquitectura del ovário de la langosta de Juan Fernández, Jasus frontalis. Rev. Invest. Mar., 28: 175-194.

Eurenius, L. - 1973. An electron microscope study on the developing oocytes of the crab Cancer pagurus $\mathrm{L}$. With special reference to yolk formation (Crustacea). Z. Morph. Tiere., 75: 243-254.

Ganion, L.R. and R.G. Kessel. - 1972. Intracellular synthesis, transport and packaging of proteinaceous yolk in oocytes of Orconectes immunis. J. Cell. Biol., 52: 420-424.

Garcia, T.M. and J.R.F. Silva. - 2006. Testis and vas deferens morphology of the red-clawed mangrove tree crab (Goniopsis cruentata) (Latreille, 1803). Brazilian Arch. Biol. Tech., 49 (2): 339-345. 
Hinsch, G.W. and M.V. Cone. - 1969. Ultrastructural observations of vitellogenesis in the spider crab, Libinia emarginata. L. $J$. Cell. Biol., 40: 336-342.

Hinsch, G.W. - 1972. Some factors controlling reproduction in the spider crab, Libinia emarginata. Biol. Bull., 143: 358-366.

Hinsch, G.W. - 1992. Ovary of the Golden Crab, Chaceon fenneri: I. Post-Spawning and Oosorption. J. Morphol., 211: 1-6.

Ituarte, R.B., E.D. Spivak and T.A. Luppi. - 2004. Female reproductive cycle of the Southwestern Atlantic estuarine crab Chasmagnathus granulatus (Brachyura: Grapsoidea: Vanuridae). Sci. Mar., 64 (1): 127-137.

Johnson, P.T. - 1980. Histology of the blue crab, Callinectes sapidus: a model for the Decapoda. Praeger, New York.

Junqueira, L.C. and L.M.M.S. Junqueira. - 1983. Técnicas básicas de Citologia e Histologia. Livraria e Editora Santos, São Paulo.

Kaestner, A. - 1970. Class Crustacea: Reproduction, Development, and Relationships. In: A. Kaestner, Invertebrate Zoology, pp. 35-76. Wiley, New York.

Kessel, R.G. - 1968. Mechanisms of protein yolk synthesis and deposition in crustacean oocytes. Z. Zellforschung, 89: 17-38.

Kessel, R.G. and H.W. Beams. - 1968. Intranucleolar membranes and nuclear-cytoplasmic exchange in young crayfish oocytes. $J$. Cell Biol., 39: 735-741.

King, J.E. - 1948. A study of reproduction of the common marine shrimp, Pennaeus setiferus (Linnaeus). Bio. Bull. Mar. Lab. 94: 242-252.

Krol, R.M., W.E. Hawkins and R.M. Overstreet. - 1992. Reproductive Components. In: F.W. Harrison and A.G. Humes. Microscopic Anatomy of invertebrates: Decapod Crustacea. v. 10, pp. 259-343. Wiley-Liss, Inc.

Kulkarni, G.K., L. Glade and M. Fingerman. - 1991. Oogenesis and effects of neuroendocrine tissues on in vitro synthesis of protein by the ovary of the red swamp crayfish Procambarus clarkii (Girard). J. Crustac. Biol., 11(4): 513-522.

Lanteigne, C., P.G. Beninger and C. Gionet. -1996. Ontogeny of female primary sexual characters in the majid crabs Chionoecetes opilio and Hyas coarctatus. J. Crustac. Biol., 16(3): 501-514.

Leite, M.M.L. - 2005. Relções Morfométricas para a compreensão de aspectos reprodutivo do caranguejo-Uça Ucides cordatus (Linnaeus, 1763), no estuário do Rio Coreú-Ceará. Master dissertation, Univ. Ceará

López, L.S.G., V.S. Stella and E.M. Rodrígues. - 1997. Size at onset of sexual maturity in Chasmagnathus granulata (Decapoda, Brachyura). Nauplius, 5(2): 65-75.

Mello, M.L.S. and B.C. Vidal. - 1980. Práticas de Biologia Celular, p.62, São Paulo: Edgar Blucher.

Melo, G.A.S. - 1996. Manual de identificação dos Brachyura (caranguejos e siris) do litoral brasileiro. Plêiade, FAPESP, São Paulo.

Minagawa, M.J., M. Chiu, F. Kudo and F. Takashima. - 1993. Female reproductive biology and oocyte development of the red frog crab, Ranina ranina, off Hachijojima, Izu islands, Japan. Mar. Biol., 115: 613-623.

Moura, N.F.O. and P.A. Coelho. - 2003. Fecundidade de Goniopsis cruentata (Latreille, 1803) (Crustácea, Brachyura, Grapsidae) no manguezal do Rio Paripe - Pernambuco - Brasil. Trop. Oceanogr., 31(2): 127-133.
Moura, N.F.O and P.A. Coelho. - 2004. Maturidade sexual fisiológica em Goniopsis cruentata (Latreille) (Crustacea, Brachyura, Grapsidae) no Estuário do Rio Paripe, Pernambuco, Brasil. Rev. Bras. Zool., 21(4): 1011-1015.

Mota-Alves, M.I. - 1975. Sobre a reprodução do caranguejo-uçá, Ucides cordatus (Linnaeus), em mangues do Estado do Ceará (Brasil). Arq. Cienc. Mar., 15: 85-91.

Mota-Alves, M.I. and G.S. Tomé. - 1966. Estudo sobre as gônadas da lagosta Panulirus Laevicauda (Latr.) Arq. Est. Biol. Mar. Univ. Fed. Ceará, 6(1): 1-9.

Mota, M.I. and G.S. Tomé. - 1965. On the histological structure of the gonads of Panulirus Argus (Latr.). Arq. Est. Biol. Mar. Univ. Fed. Ceará, 5(1): 15-26.

Pearse, A.G.E. - 1960. Histochemistry theoretical and applied, v. 2. Jet. Churchill Ltd., London.

Pinheiro, M.A.A. and A. Fransozo. - 1998. Sexual maturity of the speckled crab Aranaeus cribarius (Lamarck, 1818) (Decapoda: Brachyura: Portunidae), in the Ubatuba Littoral, São Paulo State, Brazil. Crustac. Int. J. Crustac. Res., 71(4): 434-452.

Reigada, A.L.D. and M.L. Negreiros-Fransozo. - 2000. Reproductive cycle of Hepatus pudibundus (Herbst, 1785) (Crustacea: Decapoda: Calappidae) in Ubatuba, Sp, Brazil. Rev. Brasil. Biol., 60(3): 483-491.

Ryan, E.P. - 1967. Structure and function of the reprductive system of the crab Portunus sanguinolentus (Herbst) (Brachyura: Portunidae). II. The Female system. Proc. Symp. Crustacea Mar. Biol. Ass. India, p. 522-544.

Ross, M.H., E.J. Reith and L.J. Rowrell. - 1993. Histologia: texto e atlas. 2nd ed. Panamericana, São Paulo.

Rotllant, G., E. González-Gurriarán, L. Fernandez, K. Benhalima and E. Ribes. - 2007. Ovarian maturation of the multi-spawning spider crab Maja brachydactyla (Decapoda: Majidae) with special reference to yolk formation. Mar. Biol., 152: 383-394.

Santana, G.X. - 2002. Caracterização morfológica do sistema reprodutor feminino do caranguejo uca Ucides cordatus (Linnaeus, 1763) (Decapoda Ocypodae). Monograph, Universidade Federal do Ceará, Ceará.

Silva, J.R.F. - 1999. Estudo morfológico em ovários de lagostas do gênero Panulirus White, 1847, (Decapoda, Palinuridae). Ph. D. thesis, Univ. São Paulo.

Silva, J.R.F. and C. Cruz-Landim. - 2006. Macroscopic aspects and scanning electron microscopy of the ovaries of the Spiny Lobsters Panulirus (Crustacea: Decapoda). Braz. J. Morphol. Sci., 23(3-4): 479-486.

Tolosa, E.M.C., C.J. Rodrigues, O.A. Behmer and A.G. FreitasNeto. - 2003. Manual de técnicas histológica normal e patológica, 2nd ed. Manole, São Paulo.

Travis, D.F.I. - 1955. Pre-ecdysal histological and histochemical changes in the hepatopancreas and integumental tissues. Bio. Bull. Mar. Biol., 108: 88-112.

Varadarajan, S. and T. Subramoniam. - 1980. Histological changes during vitellogenesis in the ovary of the hermit crab Clibanarius clibanarius. Proc. Indian nat. Sci. Acad., 46(5): 645-651.

Scient. ed.: P. Abelló

Received January 21, 2008. Accepted December 15, 2008.

Published online April 27, 2009. 